\title{
13. The 2013 Federal Election: The Greens campaign
}

\author{
Andrew Bartlett
}

For a political party with a relatively short history, all elections can seem historic. However, the 2013 federal election was ground-breaking for the Greens in both positive and negative ways. For those who closely follow the fortunes of minor or 'third' parties, there were some noteworthy firsts.

The 2013 election saw a minor party (excluding the National/Country Party) retain a lower house seat for the first time, with Adam Bandt holding on to the seat of Melbourne with a swing of more than 7 per cent towards the Greens, taking his primary vote to 42.62 per cent. Senators Peter Whish-Wilson (Tasmania) and Sarah Hanson-Young (South Australia) were returned and Janet Rice was elected from Victoria. While Scott Ludlam was also deemed to be reelected following the recount of the Western Australian Senate vote, this entire Senate contest was subsequently voided by a High Court judge sitting as the Court of Disputed Returns. Ultimately, Ludlam was successful again at the rerunning of the Western Australian Senate contest and the Greens now hold 10 Senate seats. This is not only the Greens' highest ever number of seats held, but the highest ever for any minor party, beating the nine seats the Democrats held following the 1998 federal election. Measuring political success by that base indicator - representation in parliament - in 2013 the Greens did well, at the very least holding their ground in an electoral environment far less favourable than that faced three years earlier.

\section{New leadership for the Greens}

It was widely noted that this was the first election for the Australian Greens without former senator Bob Brown as parliamentary leader, ${ }^{1}$ a position he had held since first entering the Senate in 1996. Christine Milne became only the second parliamentary leader of the Greens and Adam Bandt became the deputy leader. Many commentators saw this as a major test for the party and for Christine Milne with her different style of leadership. Bob Brown's retirement

1 There had been Senators for the Western Australian Greens from the late 1980s to 1998, but at that time the Western Australian Greens were structurally separate from the national Greens party. 
from Parliament in June 2012 led to many predictions that this would see the Greens follow the same path to extinction that had befallen the Australian Democrats, increasing the expectations and pressure on Christine Milne.

However, this supposed parallel was always an overly simplistic and factually flawed one. When Don Chipp - the Democrats founder and in that respect quasiequivalent to Bob Brown-retired in 1986, also being succeeded by the party's first female leader, the same predictions of extinction were made. Yet history shows that at Janine Haines' first election as leader in 1987, the Democrats managed to retain the same number of Senate seats and went on to achieve their highest ever vote at the following election in 1990. Christine Milne has now passed the same test, with the Greens managing to hold the lower house seat as well as winning one extra seat in the Senate.

\section{Background context: Comparing the 2007 and 2010 elections}

Most commentators have focused their observations not so much on the 2013 outcome in terms of seats for the Greens, but on the swing suffered by the party. Nationally, the Greens vote fell from 11.76 per cent in the House of Representatives and 13.1 per cent in the Senate to 8.65 per cent in both Houses. No state or territory was immune from the swing away from the Greens, but the size was varied across the country - with the smallest in New South Wales and the largest in Tasmania.

The 2010 election was a high point in the Greens' electoral history. It was the first time any minor party had won a Senate seat in every state, and the Greens managed a historic breakthrough with Adam Bandt's election in the House of Representatives seat of Melbourne. The Greens' primary vote had been steadily increasing at each election since 1996, but jumped significantly in 2010. The successes of 2010 meant that the Greens were able to support the ALP to form a minority government. This meant that positive outcomes and key Greens policies were achieved. The first steps for Denticare were made, the Parliamentary Budget Office was established, and of course the Clean Energy package, including carbon pricing and the establishment of the Clean Energy Finance Corporation.

The Coalition's successful demonisation of the carbon tax and the difficult political circumstances created by the Greens' perceived association with an unpopular Labor Party meant that a decrease in vote share was expected. However, the size of the decline in the Senate vote in some states was concerning for the party. 


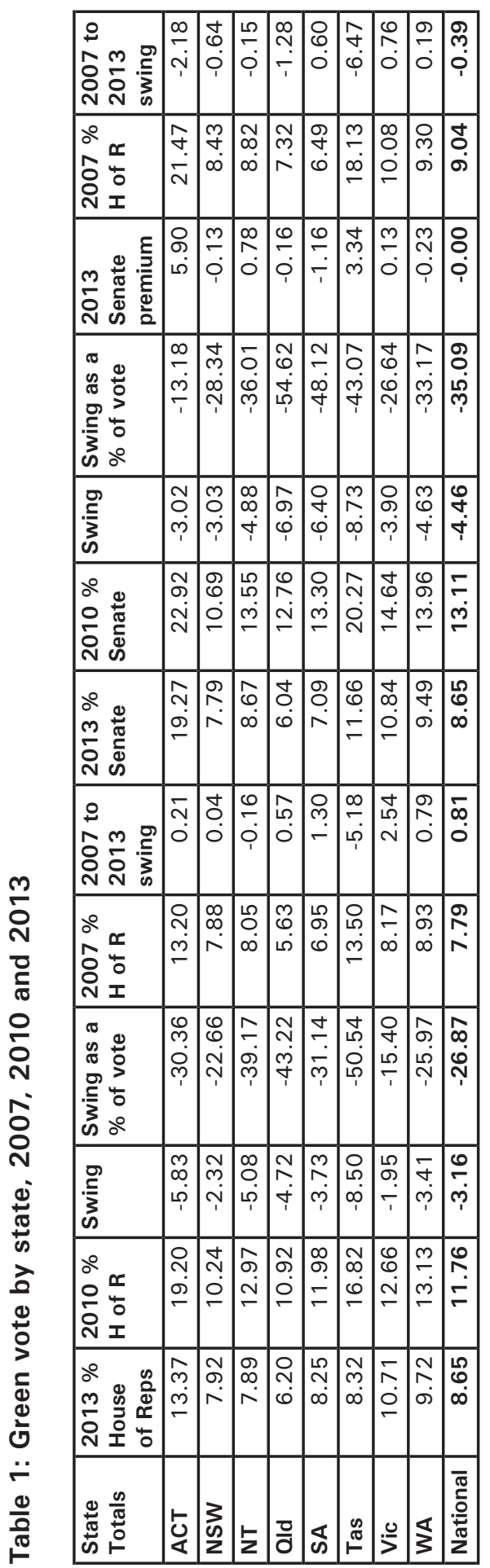

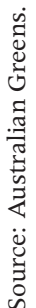


Table 2: Green vote in the House of Representatives, 2013-highest vote

\begin{tabular}{|c|c|c|c|c|c|c|c|c|c|}
\hline Electorate & Gender & $\begin{array}{l}2013 \\
\%\end{array}$ & $\begin{array}{l}2010 \\
\%\end{array}$ & Swing & \begin{tabular}{|l|} 
Swing \\
as a \\
$\%$ of \\
vote \\
\end{tabular} & $\begin{array}{l}2007 \\
\%\end{array}$ & \begin{tabular}{|l|}
2007 \\
to \\
2013 \\
swing \\
\end{tabular} & $\begin{array}{l}\text { State and } \\
\text { Demographic }\end{array}$ & Enrolment \\
\hline Melbourne & $\mathrm{m}$ & 42.62 & 36.17 & 6.45 & 17.00 & 22.80 & 19.82 & $\begin{array}{r}\text { Vic inner } \\
\text { metropolitan }\end{array}$ & 97,277 \\
\hline Batman & $f$ & 25.96 & 23.48 & 2.48 & 10.56 & 17.17 & 8.79 & $\begin{array}{r}\text { Vic inner } \\
\text { metropolitan }\end{array}$ & 100,456 \\
\hline Grayndler & $\mathrm{m}$ & 22.90 & 25.90 & -3.00 & -11.58 & 18.70 & 4.20 & $\begin{array}{r}\text { NSW inner } \\
\text { metropolitan }\end{array}$ & 97,203 \\
\hline Wills & $\mathrm{m}$ & 21.19 & 20.60 & 0.59 & 2.86 & 13.82 & 7.37 & $\begin{array}{r}\text { Vic inner } \\
\text { metropolitan } \\
\end{array}$ & 63,060 \\
\hline $\begin{array}{l}\text { Melbourne } \\
\text { Ports }\end{array}$ & $f$ & 20.04 & 20.66 & -0.62 & -3.00 & 15.03 & 5.01 & $\begin{array}{r}\text { Vic inner } \\
\text { metropolitan } \\
\end{array}$ & 100,075 \\
\hline Richmond & $f$ & 17.34 & 16.15 & 1.19 & 7.37 & 14.93 & 2.41 & NSW rural & 94,247 \\
\hline Sydney & $f$ & 17.30 & 23.75 & -6.45 & -27.16 & 20.71 & -3.41 & $\begin{array}{r}\text { NSW inner } \\
\text { metropolitan }\end{array}$ & 99,999 \\
\hline Gellibrand & $\mathrm{m}$ & 16.49 & 15.35 & 1.14 & 7.43 & 9.38 & 7.11 & $\begin{array}{r}\text { Vic inner } \\
\text { metropolitan } \\
\end{array}$ & 94,121 \\
\hline Kooyong & $f$ & 16.14 & 18.48 & -2.34 & -12.66 & 11.82 & 4.32 & $\begin{array}{r}\text { Vic inner } \\
\text { metropolitan }\end{array}$ & 97,046 \\
\hline Higgins & $\mathrm{m}$ & 15.87 & 17.9 & -2.03 & -11.34 & 10.75 & 5.12 & $\begin{array}{r}\text { Vic inner } \\
\text { metropolitan } \\
\end{array}$ & 101,202 \\
\hline Goldstein & $f$ & 15.85 & 16.21 & -0.36 & -2.22 & 10.37 & 5.48 & $\begin{array}{r}\text { Vic inner } \\
\text { metropolitan }\end{array}$ & 102,115 \\
\hline Warringah & $\mathrm{m}$ & 15.40 & 16.34 & -0.94 & -5.75 & 12.53 & 2.87 & $\begin{array}{r}\text { NSW inner } \\
\text { metropolitan }\end{array}$ & 95,370 \\
\hline Curtin & $f$ & 15.19 & 17.72 & -2.53 & -14.28 & 13.45 & 1.74 & $\begin{array}{r}\text { WA inner } \\
\text { metropolitan }\end{array}$ & 106,303 \\
\hline $\begin{array}{l}\text { North } \\
\text { Sydney }\end{array}$ & $f$ & 15.14 & 15.53 & -0.39 & -2.51 & 9.21 & 5.93 & $\begin{array}{r}\text { NSW inner } \\
\text { metropolitan }\end{array}$ & 97,113 \\
\hline Wentworth & $\mathrm{m}$ & 14.78 & 17.44 & -2.66 & -15.25 & 14.96 & -0.18 & $\begin{array}{r}\mathrm{NSW} \text { inner } \\
\text { metropolitan }\end{array}$ & 88,324 \\
\hline Ryan & $\mathrm{m}$ & 14.33 & 18.96 & -4.63 & -24.42 & 9.43 & 4.90 & $\begin{array}{r}\text { Qld outer } \\
\text { metropolitan }\end{array}$ & 100,943 \\
\hline Brisbane & $f$ & 14.15 & 21.28 & -7.13 & -33.51 & 11.80 & 2.35 & $\begin{array}{r}\text { Qld inner } \\
\text { metropolitan }\end{array}$ & 137,895 \\
\hline Mackellar & $\mathrm{m}$ & 14.14 & 16.77 & -2.63 & -15.68 & 11.72 & 2.42 & $\begin{array}{r}\text { NSW outer } \\
\text { metropolitan }\end{array}$ & 102,327 \\
\hline Mayo & $\mathrm{m}$ & 13.95 & 16.97 & -3.02 & -17.80 & 10.96 & 2.99 & SA rural & 65,856 \\
\hline Fraser & $\mathrm{m}$ & 13.90 & 19.84 & -5.94 & -29.94 & 13.38 & 0.52 & $\begin{array}{r}\text { ACT inner } \\
\text { metropolitan } \\
\end{array}$ & 94,112 \\
\hline Jagajaga & $\mathrm{m}$ & 12.85 & 14.95 & -2.10 & -14.05 & 10.25 & 2.60 & $\begin{array}{r}\text { Vic inner } \\
\text { metropolitan } \\
\end{array}$ & 98,484 \\
\hline Bradfield & $f$ & 12.73 & 16.34 & -3.61 & -22.09 & 11.26 & 1.47 & $\begin{array}{r}\mathrm{NSW} \text { inner } \\
\text { metropolitan }\end{array}$ & 103,012 \\
\hline Canberra & $f$ & 12.49 & 18.56 & -6.07 & -32.70 & 12.95 & -0.46 & $\begin{array}{r}\text { ACT inner } \\
\text { metropolitan }\end{array}$ & 102,918 \\
\hline Cowper & $f$ & 12.22 & 9.09 & 3.13 & 34.43 & 11.04 & 1.18 & NSW rural & 100,280 \\
\hline Franklin & $f$ & 12.13 & 20.87 & -8.74 & -41.88 & 14.44 & -2.31 & $\begin{array}{r}\text { Tas outer } \\
\text { metropolitan }\end{array}$ & 102,768 \\
\hline
\end{tabular}


13. The 2013 Federal Election

\begin{tabular}{|l|l|l|l|l|l|r|r|r|r|}
\hline Electorate & Gender & $\begin{array}{l}\mathbf{2 0 1 3} \\
\%\end{array}$ & $\begin{array}{l}2010 \\
\%\end{array}$ & Swing & $\begin{array}{l}\text { Swing } \\
\text { as a } \\
\% \text { of } \\
\text { vote }\end{array}$ & $\begin{array}{l}2007 \\
\%\end{array}$ & $\begin{array}{l}2007 \\
\text { to } \\
2013 \\
\text { swing }\end{array}$ & $\begin{array}{l}\text { State and } \\
\text { Demographic }\end{array}$ & Enrolment \\
\hline Newcastle & $\mathrm{f}$ & 11.81 & 15.47 & -3.66 & -23.66 & 10.01 & 1.80 & $\begin{array}{r}\text { NSW } \\
\text { provincial }\end{array}$ & 95,395 \\
\hline Fremantle & $\mathrm{m}$ & 11.78 & 17.65 & -5.87 & -33.26 & 14.57 & -2.79 & $\begin{array}{r}\text { WA inner } \\
\text { metropolitan }\end{array}$ & 103,393 \\
\hline Corangamite & $\mathrm{m}$ & 11.71 & 11.43 & 0.28 & 2.45 & 7.97 & 3.74 & $\begin{array}{r}\text { Vic } \\
\text { provincial }\end{array}$ & 93,264 \\
\hline Boothby & $\mathrm{m}$ & 11.67 & 13.24 & -1.57 & -11.86 & 10.22 & 1.45 & $\begin{array}{r}\text { SA outer } \\
\text { metropolitan }\end{array}$ & 97,787 \\
\hline Cunningham & $\mathrm{f}$ & 11.49 & 15.12 & -3.63 & -24.01 & 14.63 & -3.14 & $\begin{array}{r}\text { NSW outer } \\
\text { metropolitan }\end{array}$ & 95,317 \\
\hline Swan & $\mathrm{m}$ & 11.38 & 11.81 & -0.43 & -3.64 & 10.13 & 1.25 & $\begin{array}{r}\text { WA inner } \\
\text { metropolitan }\end{array}$ & 105,317 \\
\hline Stirling & $\mathrm{m}$ & 11.18 & 12.90 & -1.72 & -13.33 & 7.56 & 3.62 & $\begin{array}{r}\text { WA inner, } \\
\text { metropolitan }\end{array}$ & 94,919 \\
\hline Pearce & $\mathrm{f}$ & 11.08 & 13.24 & -2.16 & -16.31 & 8.59 & 2.49 & $\begin{array}{r}\text { WA outer } \\
\text { metropolitan }\end{array}$ & 109,262 \\
\hline
\end{tabular}

Source: Australian Greens. Table shows seats where the Greens captured 11 per cent or more of the vote.

Table 3: Green vote in the House of Representatives - seats with largest swing against the Greens

\begin{tabular}{|c|c|c|c|c|c|c|c|c|c|}
\hline Electorate & Gender & $\begin{array}{l}2013 \\
\%\end{array}$ & $\begin{array}{l}2010 \\
\%\end{array}$ & Swing & $\begin{array}{l}\text { Swing } \\
\text { as a \% } \\
\text { of vote }\end{array}$ & $\begin{array}{l}2007 \\
\%\end{array}$ & $\begin{array}{l}2007 \\
\text { to } \\
2013 \\
\text { swing }\end{array}$ & $\begin{array}{l}\text { State and } \\
\text { demographic }\end{array}$ & Enrolment \\
\hline Denison & $f$ & 7.84 & 18.98 & -11.10 & -58.69 & 18.60 & -10.76 & $\begin{array}{r}\text { Tas inner } \\
\text { metropolitan }\end{array}$ & 100668 \\
\hline Fairfax & $\mathrm{m}$ & 8.30 & 18.00 & -9.70 & -53.89 & 8.53 & -0.23 & Qld rural & 100431 \\
\hline Werriwa & $m$ & 3.25 & 12.70 & -9.45 & -74.41 & 3.79 & -0.54 & $\begin{array}{r}\text { NSW outer } \\
\text { metropolitan }\end{array}$ & 105149 \\
\hline Franklin & $f$ & 12.13 & 20.87 & -8.74 & -41.88 & 14.44 & -2.31 & $\begin{array}{r}\text { Tas outer } \\
\text { metropolitan }\end{array}$ & 102768 \\
\hline Lyons & $f$ & 8.22 & 16.75 & -8.53 & -50.93 & 11.17 & -2.95 & Tas rural & 97292 \\
\hline Fisher & $\mathrm{m}$ & 7.57 & 15.84 & -8.27 & -52.21 & 5.61 & 1.96 & Qld rural & 102122 \\
\hline Forde & $f$ & 4.16 & 12.22 & -8.06 & -65.96 & 4.80 & -0.64 & $\begin{array}{r}\text { Qld outer } \\
\text { metropolitan }\end{array}$ & 101819 \\
\hline Bass & $f$ & 7.76 & 15.58 & -7.82 & -50.19 & 15.27 & -7.51 & $\begin{array}{r}\text { Tas } \\
\text { provincial }\end{array}$ & 97915 \\
\hline Brand & $f$ & 7.27 & 14.74 & -7.47 & -50.68 & 8.60 & -1.33 & $\begin{array}{r}\text { WA outer } \\
\text { metropolitan }\end{array}$ & 96145 \\
\hline Brisbane & $f$ & 14.15 & 21.28 & -7.13 & -33.51 & 11.80 & 2.35 & $\begin{array}{r}\text { Qld inner } \\
\text { metropolitan }\end{array}$ & 137895 \\
\hline Blair & $f$ & 4.24 & 11.06 & -6.82 & -61.66 & 3.92 & 0.32 & $\begin{array}{r}\text { Qld } \\
\text { provincial }\end{array}$ & 96752 \\
\hline Braddon & $f$ & 5.14 & 11.96 & -6.82 & -57.02 & 8.14 & -3.00 & Tas rural & 102815 \\
\hline Port Adelaide & $\mathrm{m}$ & 8.44 & 15.11 & -6.67 & -44.14 & 8.76 & -0.32 & $\begin{array}{r}\text { SA inner } \\
\text { metropolitan } \\
\end{array}$ & 93894 \\
\hline Calwell & $f$ & 5.20 & 11.86 & -6.66 & -56.16 & 4.36 & 0.84 & Vic rural & 105512 \\
\hline
\end{tabular}




\begin{tabular}{|l|l|l|l|r|r|r|r|r|r|}
\hline Electorate & Gender & $\begin{array}{l}\mathbf{2 0 1 3} \\
\%\end{array}$ & $\begin{array}{l}2010 \\
\%\end{array}$ & Swing & $\begin{array}{l}\text { Swing } \\
\text { as a \% } \\
\text { of vote }\end{array}$ & $\begin{array}{l}2007 \\
\%\end{array}$ & $\begin{array}{l}2007 \\
\text { to } \\
2013 \\
\text { swing }\end{array}$ & $\begin{array}{l}\text { State and } \\
\text { demographic }\end{array}$ & Enrolment \\
\hline Wright & $\mathrm{f}$ & $\mathbf{5 . 3 5}$ & 11.95 & -6.60 & -55.23 & & 5.35 & Old rural & 102333 \\
\hline Throsby & $\mathrm{m}$ & $\mathbf{5 . 3 7}$ & 11.93 & -6.56 & -54.99 & 9.08 & -3.71 & $\begin{array}{r}\text { NSW outer } \\
\text { metropolitan }\end{array}$ & 91563 \\
\hline Sydney & $\mathrm{f}$ & $\mathbf{1 7 . 3 0}$ & 23.75 & -6.45 & -27.16 & 20.71 & -3.41 & $\begin{array}{r}\text { NSW inner } \\
\text { metropolitan }\end{array}$ & 99999 \\
\hline Oxley & $\mathrm{m}$ & $\mathbf{5 . 3 7}$ & 11.79 & -6.42 & -54.45 & 5.13 & 0.24 & $\begin{array}{r}\text { Old outer } \\
\text { metropolitan }\end{array}$ & 97275 \\
\hline Wakefield & $\mathrm{f}$ & $\mathbf{5 . 0 7}$ & 11.30 & -6.23 & -55.13 & 4.13 & 0.94 & SA rural & 73859 \\
\hline Canberra & $\mathrm{f}$ & $\mathbf{1 2 . 4 9}$ & 18.56 & -6.07 & -32.70 & 12.95 & -0.46 & $\begin{array}{r}\text { ACT inner } \\
\text { metropolitan }\end{array}$ & 102918 \\
\hline Indi & $\mathrm{f}$ & $\mathbf{3 . 4 0}$ & 9.45 & -6.05 & -64.02 & $\mathbf{7 . 5 8}$ & -4.18 & Vic rural & 95691 \\
\hline
\end{tabular}

Source: Australian Greens. Table shows seats with swings against the Greens of 6 percentage points or more.

Greens strategists recognised early that given the different circumstances of the 2013 election, a repeat of or an increase on the success of 2010 was highly unlikely. Instead, the 2007 federal election was used as the party's benchmark, partly to ensure realistic expectations and, at least with respect to South Australia, because Nick Xenophon was also due for re-election in this cycle. When Kevin Rudd resumed leadership of the ALP, this became further justification to use 2007 as a benchmark to measure our performance.

Compared to 2007 the Greens' House of Representative vote continued its upward trend. Ninety-four out of 150 seats did better in 2013 compared to 2007. However, due in no small part to the continuing proliferation of micro and single-issue parties, the Senate vote declined below trend.

Table 4: Green vote in the House of Representatives-largest swings to and against the Greens, 2007 v 2013

\begin{tabular}{|l|l|r|r|r|r|r|r|r|r|}
\hline Electorate & Gender & $\begin{array}{l}2013 \\
\%\end{array}$ & $\begin{array}{l}2010 \\
\%\end{array}$ & Swing & $\begin{array}{l}\text { Swing } \\
\text { as a \% } \\
\text { of vote }\end{array}$ & $\begin{array}{l}2007 \\
\%\end{array}$ & $\begin{array}{l}\mathbf{2 0 0 7} \text { to } \\
\mathbf{2 0 1 3} \\
\text { swing }\end{array}$ & $\begin{array}{l}\text { State and } \\
\text { demographic }\end{array}$ & Enrolment \\
\hline Melbourne & $\mathrm{m}$ & 42.32 & 36.17 & 6.15 & 17.00 & 22.80 & $\mathbf{1 9 . 5 2}$ & $\begin{array}{r}\text { Vic inner } \\
\text { metropolitan }\end{array}$ & 97277 \\
\hline Batman & $\mathrm{f}$ & 25.96 & 23.48 & 2.48 & 10.56 & 17.17 & $\mathbf{8 . 7 9}$ & $\begin{array}{r}\text { Vic inner } \\
\text { metropolitan }\end{array}$ & 100456 \\
\hline Wills & $\mathrm{m}$ & 21.19 & 20.60 & 0.59 & 2.86 & 13.82 & $\mathbf{7 . 3 7}$ & $\begin{array}{r}\text { Vic inner } \\
\text { metropolitan }\end{array}$ & 63060 \\
\hline Gellibrand & $\mathrm{m}$ & 16.49 & 15.35 & 1.14 & 7.43 & 9.38 & $\mathbf{7 . 1 1}$ & $\begin{array}{r}\text { Vic inner } \\
\text { metropolitan }\end{array}$ & 94121 \\
\hline Durack & $\mathrm{m}$ & 6.97 & 9.25 & -2.28 & -24.65 & & $\mathbf{6 . 9 7}$ & WA rural & 94735 \\
\hline $\begin{array}{l}\text { North } \\
\text { Sydney }\end{array}$ & $\mathrm{f}$ & 15.14 & 15.53 & -0.39 & -2.51 & 9.21 & $\mathbf{5 . 9 3}$ & $\begin{array}{r}\text { NSW inner } \\
\text { metropolitan }\end{array}$ & 97113 \\
\hline
\end{tabular}




\begin{tabular}{|c|c|c|c|c|c|c|c|c|c|}
\hline Electorate & Gender & $\begin{array}{l}2013 \\
\%\end{array}$ & $\begin{array}{l}2010 \\
\%\end{array}$ & Swing & $\begin{array}{l}\text { Swing } \\
\text { as a } \% \\
\text { of vote } \\
\end{array}$ & $\begin{array}{l}2007 \\
\%\end{array}$ & $\begin{array}{l}2007 \text { to } \\
2013 \\
\text { swing } \\
\end{array}$ & $\begin{array}{l}\text { State and } \\
\text { demographic }\end{array}$ & Enrolment \\
\hline Goldstein & $f$ & 15.85 & 16.21 & -0.36 & -2.22 & 10.37 & 5.48 & $\begin{array}{r}\text { Vic inner } \\
\text { metropolitan }\end{array}$ & 102115 \\
\hline Wright & $f$ & 5.35 & 11.95 & -6.60 & -55.23 & & 5.35 & Qld rural & 102333 \\
\hline Higgins & $m$ & 15.87 & 17.90 & -2.03 & -11.34 & 10.75 & 5.12 & $\begin{array}{r}\text { Vic inner } \\
\text { metropolitan }\end{array}$ & 101202 \\
\hline $\begin{array}{l}\text { Melbourne } \\
\text { Ports }\end{array}$ & $f$ & 20.04 & 20.66 & -0.62 & -3.00 & 15.03 & 5.01 & $\begin{array}{r}\text { Vic inner } \\
\text { metropolitan }\end{array}$ & 100075 \\
\hline Braddon & $f$ & 5.14 & 11.96 & -6.82 & -57.02 & 8.14 & -3.00 & Tas rural & 102815 \\
\hline Cunningham & $f$ & 11.49 & 15.12 & -3.63 & -24.01 & 14.63 & -3.14 & $\begin{array}{r}\text { NSW outer } \\
\text { metropolitan }\end{array}$ & 95317 \\
\hline Sydney & $f$ & 17.30 & 23.75 & -6.45 & -27.16 & 20.71 & -3.41 & $\begin{array}{r}\text { NSW inner } \\
\text { metropolitan }\end{array}$ & 99999 \\
\hline Blaxland & $\mathrm{m}$ & 2.86 & 6.26 & -3.40 & -54.31 & 6.46 & -3.60 & $\begin{array}{r}\text { NSW inner } \\
\text { metropolitan }\end{array}$ & 72194 \\
\hline Throsby & $\mathrm{m}$ & 5.37 & 11.93 & -6.56 & -54.99 & 9.08 & -3.71 & $\begin{array}{l}\text { NSW outer } \\
\text { metropolitan }\end{array}$ & 91563 \\
\hline Indi & $f$ & 3.40 & 9.45 & -6.05 & -64.02 & 7.58 & -4.18 & Vic rural & 95691 \\
\hline Bass & $f$ & 7.76 & 15.58 & -7.82 & -50.19 & 15.27 & -7.51 & Tas provincial & 97915 \\
\hline Denison & $f$ & 7.84 & 18.98 & -11.10 & -58.69 & 18.6 & -10.76 & $\begin{array}{r}\text { Tas inner } \\
\text { metropolitan }\end{array}$ & 100668 \\
\hline
\end{tabular}

Source: Australian Greens. Table shows seats with swings of 5 per cent or more towards the Greens, and seats with swings of 3 per cent or more against the Greens.

The Greens in 2010 had benefitted in part from voters protesting against having to vote for the ALP or the Coalition. In 2013, there were many more choices in this regard. The cashed-up Palmer United Party, Katter's Australia Party, the Wikileaks Party and the Pirate Party, along with an explosion of other micro and single-issue parties, gave voters more choice than ever before. The voters took up this choice - the vote for the ALP and Coalition fell from 81.55 per cent in 2010 to 78.93 per cent in 2013 in the House and from 73.76 per cent to 67.83 per cent in the Senate. Both of these figures are record lows for the combined ALP-Coalition vote at a federal election (Green 2013). The fact that nearly one in three voters supported minor parties and independents ahead of Labor and the Coalition in the Senate is a significant outcome that has not received a great deal of attention. The long-standing upward trend in voting away from Labor and the Coalition, particularly in the Senate, has fully recovered from the slump generated by the Democrats' protracted death throes across the 2004 and 2007 elections.

However, this time around the Greens were not so much the beneficiary of the decline of the major party vote. Some post-election analysis conducted internally by the Greens suggests that a significant number of voters switched 
their 'protest' vote from the Greens to the Palmer United Party, whose TV advertising spend came close to matching that of the major parties in the final weeks of the campaign.

\section{The Greens campaign}

The re-election of Adam Bandt was established as a major goal of the Greens 2013 election strategy a long way in advance. The Melbourne campaign was organised very early on and modelled in part on the '08 and '12 Obama campaigns, although obviously on a much smaller scale. Using tailored messaging and theming, the Greens dominated the local Melbourne outdoor advertising space and backed this up with a very intensive and systematic door-knocking campaign over a prolonged period. Despite regular favourable opinion polling, many commentators seemed to have difficulty accepting the strength of the Greens campaign in this area. In the end, Adam Bandt achieved a primary vote of 42.62 per cent with a 7.03 per cent swing. This is the fourth highest primary vote percentage for a Greens candidate contesting a federal single seat electorate anywhere in the world (see Global Greens n.d. ${ }^{2}$ ). As perhaps one indication of Adam Bandt's personal vote compared to the generic level of support for the Greens, Bandt's House of Representatives vote was 7.18 per cent higher than the votes cast by Melbourne voters for the Greens in the Senate.

The greater embrace of social media campaigning by all the main parties was another key development in 2013 and the Greens were at the forefront in this area. Many Greens candidates had higher social media profiles than their major party opponents. Christine Milne live tweeted the leaders' debates to ensure that more than two voices were heard, as Bob Brown had done in 2010. Senator Scott Ludlam and Adam Bandt used 'Ask Me Anything' forums on Reddit to reach new audiences. The Greens Food Policy was launched via Google Hangout on Air - the first major policy to be launched on social media in Australia.

Election 2013 was the Greens most successful election fundraising effort to date. While still dwarfed by the efforts of the ALP and Coalition, the Greens received substantially more in donations compared with 2010. A number of trade unions again publicly backed the Greens stance on industrial relations and opposition to university funding cuts. There was also a large focus on email and micro donations, based on techniques developed by the Obama campaign. This fundraising success occurred despite the absence of the record million dollar individual donation that was given in the 2010 election.

2 Note that at time of writing, this site had not been updated to include Bandt's 2013 result. 


\section{Shifts and patterns in the Greens' vote}

One of the developments from the 2013 election was something of a shift in the Greens 'heartland' from Tasmania to Victoria. Senator Peter Whish-Wilson filled Bob Brown's casual Senate vacancy in 2012. While Whish-Wilson has brought a stronger business and economics background to the Greens, there was an 8.61 per cent Senate vote swing against the Greens in Tasmania. Peter WhishWilson was comfortably returned as a Senator, but the swing against the party was bigger in Tasmania than in the other states and territories. Denison and Franklin also recorded the biggest and fourth biggest negative swings in House of Representatives seats.

It is reasonable to hypothesise that this was partly due to the absence of Bob Brown's considerable personal following, along with some local blowback from the Greens being seen as aligned with the not so popular local state Labor Government. Having said that, both the polls prior to the Tasmanian election and the actual outcome in March 2014 indicated a much greater decline in the local Labor vote than in support levels for the Greens.

Victoria, on the other hand, saw the smallest House of Representatives statewide swing against the Greens, and it joined Tasmania, South Australia and Western Australia as states with two Green senators. Additionally, the Greens came second on primary votes in Batman (repeated from 2010) and in Willsboth seats adjoin the seat of Melbourne. With Adam Bandt's re-election, Victoria is now the strongest state federally for the Greens in terms of seats held and percentage of the House of Representatives vote.

Overall, the Greens only recorded a positive swing in 12 of the 150 House of Representative seats - six each in New South Wales and Victoria. Ninety-four seats recorded a positive swing compared to the vote in 2007. But extrapolating the Senate vote across the House of Representatives' electorates the number of seats in which a positive swing occurred was 53.

Post-election research suggested that around one in four voters decided who they would be voting for in the final month, with as much as 16 per cent indicating they had not decided until the final week or even polling day itself. There is also a growing portion of the electorate not identifying themselves as being aligned significantly with any party. 


\section{The Greens' growing profile and influence in Australian politics}

The Greens long-standing efforts to demonstrate strength across a wide range of issues is being recognised by a growing proportion of the electorate. A roughly equivalent number of people gave 'stopping Tony Abbott getting absolute power' and climate change or the environment in general as their most important reason for voting Greens. Other issues such as a more caring society, marriage equality and refugees also were primary influences on the vote of many who supported the Greens. The ideal of having a more caring society was a key message for the Greens, and post-election research suggested that this was having some impact, with the Greens about on a par with the two larger parties in this regard. Not surprisingly, the issues with greatest cut-through for the Greens were environment-related ones. However, the Greens efforts in promoting issues aimed at assisting people meet their basic needs did not have the same impact in the election context.

One aspect to which the Greens paid considerable attention in election planning was the goal of ensuring all policies released for the election were fully costed. The Parliamentary Budget Office is a valuable new accountability mechanism which was set up following the 2010 federal election as part of the arrangement the Greens struck with Julia Gillard as she was pulling together support for a minority ALP government. The Greens parliamentary wing, using the resources of the PBO, put significant effort into developing a fully costed policy platform - another first in the party's history. This move most likely did not shift a lot of votes this time around, despite the stark contrast with the lack of costing released by the Coalition in the election lead-up. However, the Greens' costing initiatives were commented on by a number of print commentators, and this helped stymie the attacks that were likely to have appeared on this front and which had been a characteristic of the 2010 election.

This focus on showing economic accountability and credibility is a long-term goal for the Greens. This policy area is one remaining area where voters are most likely to have doubts about the Greens, and demonstrating credentials in this area is something which will be consistently pursued. Post-election research conducted by the Greens suggested that economic issues such as jobs, debt and cost of living were the vote-deciding issue for around a third of voters.

In looking at the topics where the Greens gained most media coverage during the election period proper, data indicates that preferences was most common, followed by asylum seekers, carbon tax, mining, and paid parental leave. In a 
pleasing sign for the future, the topic of policy costings was also one where the Greens did gain regular coverage - greater than the number of mentions in the context of the contest for Melbourne.

The Greens still have work to do in increasing public awareness about the party's policy achievements. Gains such as the establishment of the Parliamentary Budget Office, the initiation of Denticare (another feature of the Greens' agreement with Julia Gillard after the 2010 poll), the exploration of high-speed rail and, even to a degree, the Greens' role in bringing about the Clean Energy Act, are not as widely recognised as the party would like. But an ever increasing information base about which ways are most effective at reaching the electorate should assist in improving that situation.

The high level of media attention on the Greens in the context of stories about preferences was in large part due to the coverage of the Liberal Party's announcement that it would be putting the Greens last, or close to last, on howto-vote cards and in its Senate preference allocations. The determination of the Liberals to do this saw them place the Greens lower in Senate above-the-line preferences in some states than a number of extremist and racist parties such as Australia First, Rise Up Australia, the Citizens Electoral Council and One Nation. Nevertheless, this action by the Liberal Party makes it even more significant that Adam Bandt managed to retain his House of Representatives seat, with a minimal swing against him in two-party-preferred terms.

\section{Conclusion}

In the context of the 2013 election, delivering a change of government, with a new Greens leader with only a little over a year in the saddle and an increase in populist candidates from other parties, the Greens can be considered to have done quite well. Notwithstanding the decline in their primary vote from 2010, the return of Adam Bandt, the retention of three Senators plus the election of a new Senator in Victoria, mean the Greens can continue to look positively towards the future. Whilst the party still faces significant challenges in its overarching goal of building its primary vote to a level that can further challenge the centurylong stranglehold that Labor and the Coalition have had over Australia's political system, there are strong foundations which will assuredly see the Greens soon become unchallenged on almost any measure as the most successful third party in Australian political history. 


\section{References}

Global Greens. n.d. 'Greens Elected in Federal Single Seat Elections'. Viewed 28 February 2014: <www.globalgreens.org/officeholders/elected-federalsingle-seat $>$.

Green, Antony. 2013. 'Record Vote for Minor Parties at 2013 Federal Election'. Antony Green's Election Blog, 19 November, viewed 11 March 2014: <blogs. abc.net.au/antonygreen/2013/11/record-vote-for-minor-parties-at-2013federal-election.html>. 
This text taken from Abbott's Gambit: The 2013 Australian Federal Election, edited by Carol Johnson and John Wanna, published 2015 by ANU Press, The Australian National University, Canberra, Australia. 